\title{
"Religion is a Personal Choice, but Race is your very Blood!"An Analysis of White Nationalist Belief Systems
}

\author{
By Dianne Dentice
}

For many self-identified white nationalists, race and religion are equally important and closely connected. As the movement continues to evolve, a convergence of Christian Identity and pagan beliefs is producing subtle ideological shifts between disparate groups such as the Ku Klux Klan and neo-Nazis. This article exams the various religious perspectives of individuals who participated in discussion forums and nonscientific polls on Stormfront, a hate related Internet site. Additional data came from members of a Christian Identity sect in Zinc, Arkansas. Findings indicate that there is religious diversity in the white nationalist movement. Lines also appear to blur a bit between pseudo-religions and Christianity, especially with regard to Christian Identity. Even though people who actively participate in the white nationalist movement appear to be a relatively small percentage of the global population, it is important to understand how racialized interpretations of the Bible proliferate pseudo-religious and pseudoscientific ideologies, especially among young people who are searching for answers to complex questions. It appears that racist and socially isolationist attitudes continue to inform a new generation of white nationalists.

Keywords: Christian Identity, Cosmotheism, Hitler, Stormfront, White nationalism.

The white nationalist movement, also known as the white power movement (Dobratz and Waldner 2016) and white supremacist movement, is an extreme right wing social movement that has international ties to the United States, Canada, Australia, and countries in Europe that include Germany, France, and England. Within the movement there are various strains of belief systems that influence white racialist religious ideology. A characteristic of the white nationalist movement is the collective sense of intimacy and esprit de corp based on race. White pride and communalism are expressed through symbols such as burning Klan crosses, the Confederate flag, and for neo-Nazis, swastikas and other white power images. The entire movement is made up of many different groups and ideologies that are ultimately united through their belief that whites are superior to all other races.

This paper analyzes a sample of discussions and non-scientific polls posted by members of an online site for self-identified white nationalists called Stormfront.

Additional data come from field work conducted with Pastor Thom Robb's Christian Identity sect in Zinc, Arkansas that began in September 2010 and ended in December 2012. The research highlights some of the different types

\footnotetext{
* Associate Professor, Stephen F. Austin State University, USA.
} 
of belief systems that inform religious perspectives of contemporary white nationalists while attempting to answer the following questions: 1) How does race inform religion in the contemporary white nationalist movement? and 2) What are some of the ways that people in the movement identify when discussing their religion and religious ideology?

\section{Race, Religion and White Supremacy}

Some of the Christian principles taught by Jesus and his Apostles oppose hatred of others while encouraging love and forgiveness. Douthat (2013) examines the paradoxical nature of Christianity, especially with regard to the life, teachings and death of Jesus Christ. He states that Christian orthodoxy tends to embrace the contradictions of gospel narratives rather than "evading" them (Douthat 2013: 153). According to Douthat, heretics throughout history have reinterpreted scriptures to suit their own purposes and further beliefs that are sometimes antithetical to Christian doctrine. He warns that Christian orthodoxy is slowly withering while heresies abound and endure in twenty-first century America (2013: 14).

A heresy that Douthat does not discuss is Christian Identity. Ostendorf (2001/2002) categorizes the belief system as a heresy that most Americans do not know about and those who do, fail to take it seriously. A message of salvation based on race was perpetuated by several charismatic Identity leaders and preachers in the United States. Wesley Swift's ministry became influential during the 1940s and he was followed by Pete Peters, pastor of the LaPorte Church of Christ and head of Scriptures for America Worldwide international outreach ministry. According to Barkun (2006:61), Peters was also associated with the Christian Patriots, a strange combination of religious and political fanatics often driven by conspiracy theories. Currently Pastor Thom Robb who is in his mid-seventies heads a Christian Identity sect in Arkansas which this paper will examine.

A contingent of hard core far right religious zealots, influenced by the late Swift along with Peters and Robb, reject traditional Christian ideals of social justice and tolerance. They base their version of Christianity on the supremacy of the white race above all others. Among their worst enemies are Jews and non-Jewish supporters of the state of Israel. Christian Identity believers maintain that Anglo-Saxons are the true children of Israel and Jews are the spawn of Satan (Goldberg 2007: 45). Acknowledging the fact that Identity theology is a thorn in the side of mainstream Christianity, Kaplan (1993) wrote that Identists are not prone to domestic terrorism but are retreatists who prefer withdrawal to engagement with the dominant culture.

Sharpe (2000) argues that even if Christian Identists are not involved in overt terrorism, the principles of their religious perspective justify acts of violence against federal government agents and leaders, non-whites, homosexuals, and Jews. Making connections to extreme social conservative positions of groups such as the Council for National Policy, Goldberg (2007: 55) states that paranoia, 
populism, and nationalist tendencies of America's far right create a frightening scenario reminiscent of Hitler's political agenda in Nazi Germany. Although Hitler was not particularly religious, he believed in God and practiced "positive Christianity", a pseudo-religious perspective originating during the 1880s with Germany's Christian Social movement (Vierick 1941/1961: 168). Christian Nationalism, identified by Goldberg (2007), is similar to the German movement and contains anti-Semitic ideology and rhetoric.

Dobratz (2001) argues there are three different white nationalist belief systems: 1) Christian Identity, 2) Church of the Creator, and 3) Odinism. According to Dobratz, a primary function of the different ideologies is to strengthen the racial identity of movement activists who belong to a variety of different groups. The belief in white superiority is one of the things that they all agree on. At the same time, she argues that all three belief systems are oppositional which suggests there is no guarantee of unity in the contentious, often hostile environment that characterizes the white nationalist movement. This assessment differs from Barkun (1994) and Zeskind (2009) who both emphasize the importance of Christian Identity to white nationalism's theological perspective.

One of the most influential and least written about religious and political leaders of the white nationalist movement is the late Wesley Swift, who founded the Church of Jesus Christ Christian in 1945. Milwicki (2014/2015: 94) found that Swift's brand of Identity theology still serves as a bridge to connect white supremacist and religious right wing networks of activists. Milwicki cites Swift's beliefs that both of America's political parties and the armed forces were controlled by Jews. A millenialist at heart, Swift predicted that Christian Identity was the force that would free Americans from their Jewish oppressors and the final race war would be waged on American soil. Many contemporary Christian Identists such as Pastor Robb still embrace Swift's apocalyptic view. Milwicki (2014/2015) also argues that Swift's influence goes even deeper with links to the American prison system and the Aryan Brotherhood. Swift's legacy cannot be overestimated as a political and religious force that serves as a call to arms to fix what is ailing America.

\section{Theorizing Racist Pseudo-Religious Perspectives}

Simi and Futrell (2010: 10) identify four distinct branches of the white power movement that include the Ku Klux Klan, Christian Identity, neo-Nazis, and racist skinheads. The authors hypothesize that even though collective belief systems within the movement tend to be fragmented and in some cases overlap; the above named factions are connected by basic beliefs, especially about race, that transcend whatever ideological differences group members may otherwise have. Neo-Nazis exemplify the cross-pollination process that carries over between the various groups and specifically within the Christian Identity wing of the movement (Milwicki 2014/2015, Simi and Futrell 2010, Zeskind 2009). In some ways neo-Nazi beliefs and Christian Identity beliefs 
are becoming more interconnected, partially because race is so important to people who align with the broader movement.

The American racist skinhead movement has direct connections to the second-wave National Front (NF) which was born in 1967 in Great Britain (Simi and Futrell 2010). Ideology of the NF adhered to the core pillars of racial nationalism and quickly took the form of a neo-Nazi party (Goodwin 2011: 25). Many of the youth who were associated with the movement and the party were disenfranchised working class white males who identified as skinheads. They were also involved with the music and cultural scene of the time exemplified by bands such as the Sex Pistols. In his analysis of the youth subcultures, Hebdige (1979/2001: 67) discovered an underlying racial attitude among white punk rockers whose prejudices inhibited cultural bridge building with the reggae movement and other black musical genres of the time.

Since the 1980s American racist skinheads have synthesized neo-Nazi beliefs about white racial superiority (Simi and Futrell 2010: 15). Their idealization of classic Nordic mythology and a rudimentary (at best) understanding of Nazi spin doctors of the Third Reich has created a pseudoreligious perspective among the youth of the movement that exists in many of the posts on Stormfront. Prior to Hitler's rise in Germany, Jews were portrayed in German culture as a cursed, sinister, and dark race (Vierick 1941/1961: 168). German ideologues argued that the future of their country was dependent on defeat of the abhorrent Jewish race by Aryan warriors depicted in both literature and art as blond, powerful and handsome. Propaganda such as this helped set up Hitler's rise to power with its portrayal of Germans as the master race and Jews as something to be destroyed at all costs. Anti-Semitic attitudes still exist in forums on Stormfront that are frequented by a new generation of white racists.

The origins of Christian Identity, the second racist belief system examined in this paper, evolved from British Israelism. ${ }^{1}$ During the eighteenth century, an Irishman named John Wilson claimed to have found the origins of the nations of Europe. His lectures and books suggest that the ten lost tribes of Israel migrated from the Near East to Europe and that Jews only inherited a portion of the divine prophesies ordained by God (Barkun 1994: 7). Eventually devotees of British Israelism preached that the British Royal family was direct descendants of King David (Ostendorf 2001/2002: 37). The belief that the Anglo-Saxon race was endowed with such a great lineage became part of the broader conversation among Christian Identists such as Wesley Swift and his mentor, Gerald L. K. Smith who believed that whites were superior to all other races. Christian Identity evolved as a quasi-theological theory and leaders in the movement such as Swift held that Jews and people of color were inferiors sent to earth as a scourge of God and only whites can achieve salvation (Ridgeway 1990: 17).

\footnotetext{
${ }^{1}$ The definitive work on the connections between British Israelism and Christian Identity are covered in Barkun's Religion and the Racist Right. Refer to the reference page for the full citation.
} 
The third belief system that influences people in the white nationalist movement is Cosmotheism, the embodiment of fundamental truths about the nature of the universe, formulated by William Pierce in the 1970s. A symbol of the white power movement of the 1970s and 1980s, Pierce's ideology attracted many young, American born neo-Nazis. His religion known as Cosmotheism rejected all supernatural and unverifiable communications between a deity (God) and man. A Nazi sympathizer, physicist and professor, Pierce's scientific education informed his interpretation of the evolution of life from both 1) nonliving matter and 2) lower forms of life. The basic tenets of Cosmotheism are contained in three essays titled: 1) The Path (1977); 2) Cosmotheism: On Living Things (1979); and 3) Cosmotheism: On Society (1984).

Cosmotheism was created to show humans the meaning and the purpose of life according to Pierce's worldview. His writings encourage followers to become consciously aware of who they are (implicit in his words are "racially conscious"). Once believers achieve this awareness, they must serve the creator's purpose of uplifting their race and completing the first step to enlightenment. Highly critical of concepts of equality that are part of America's religious and cultural value system, Pierce's religious perspective is rooted in racism. He stresses survival of the white race above all else. He preached about establishing racially pure communities, avoiding interaction of any kind with people of color, and avoiding mainstream religions such as Christianity. He also rejected Christian Identity because of the connections to a Supreme Being other than man.

Durkheim (1912/1995: 2) states that all religions fulfill conditions of human existence in different ways, even racist religions such as those discussed in this paper. Each perspective outlined here expresses the collective reality of people who are anti-Semitic, racist, and in some cases non-believers. The beliefs espoused here fall into Douthat's (2013: 11) category of heresies in that they contradict mainstream Christian orthodoxy that rejects both mysticism and anti-intellectualism. The search for meaning in life involves very different paths for people of faith and others who are trying to justify their racist beliefs with some type of spiritual meaning.

\section{Data and Methods}

The data for this case study include a sample of discussion forums and nine non-scientific polls posted on Stormfront and field research in Zinc, Arkansas with a Christian Identity sect headed by Pastor Thom Robb. Pastor Robb's sect represents one of the more stable and enduring Christian Identity church communities in the United States. Stormfront was initially a private dial-in bulletin board developed by former Klansman Don Black to accommodate supporters and staff of the David Duke for Louisiana Senate Campaign in the early 1990s. In March 1995, it became the first fully online white nationalist Internet website. According to site statistics, an average of 40,000 people consistently visit the site in any given 24-hour period. Over the years researchers such as Bowman-Grieve (2008), Brown (2009), De Koster and Houtman (2008), 
Meddaugh and Kay (2009), and Weatherby and Scoggins (2005/2006) have analyzed virtual communities such as Stormfront to gain insights into how extremist movements utilize the Internet to disseminate information and recruit new members.

\section{Content Analysis of Stormfront}

The first part of this study consists of an interpretative analysis (Hijmans $1996)^{2}$ of discussions based on years of work in the field with people who identify as white nationalist and who represent many different groups in the movement. Discussions came from the Theology and Ideology and Philosophy Forums in Stormfront. I selected posts based on relevance sampling (Krippendorff 2004: 120), whereby discussants state their opinions, ask questions, and argue with each other regarding specifics about Hitler's religion, Christian Identity, and Cosmotheism. This type of sampling technique works well for a content analysis of a site such as Stormfront because it is not meant to be totally representative of the whole population of texts. As Krippendorff (2004) states, specific content excludes units that do not represent relevant information for the analysis. For example, I am only interested in discussions about Hitler's religion, Christian Identity, and Cosmotheism. The forums and sub-forums selected for this analysis deal specifically with those issues. The sample of non-scientific polls deal specifically with religious preferences of members of Stormfront.

Regarding privacy issues, there continues to be debate about whether online posts to sites such as Stormfront are public or private (Eysenbach and Till 2001, Paccagnella 1997). Most, but not all, members of the Stormfront community use pseudonyms rather than their real names. Exceptions include leaders in the movement such as Billy Roper and David Duke. According to Eysenbach and Till (2001: 1104) if a discussion contains 10 or fewer posts, the argument can be made that informed consent might be necessary. Each of the discussions contained in this analysis contained between 80 and 100 posts. The total number of posts for all three forums was 353 . Each poll had at least 50 responses.

Stormfront is international in scope and is characterized by a high level of accessibility (Bowman-Grieve 2009, De Koster and Houtman 2008). Perceived privacy for members of the site is low and site administrator, Don Black, specifically states in the FAQs section of the site that members should be aware that outsiders troll the site periodically. There are also designated individuals who monitor discussions and have the authority to disable users who violate the rules. Because of the safeguards and control mechanisms built into the site, users should be aware of the rules along with accessibility to outsiders who do not adhere to their beliefs but may peruse the site out of curiosity.

A list of nine non-scientific polls analyzed for this paper is contained in the Addendum. The poll data presents self-described religious beliefs of Stormfront

\footnotetext{
${ }^{2}$ The researcher as a competent observer of a group and/or subculture.
} 
members who participated during the time the polls were active and online. Data from polls and discussions with members of Pastor Robb's Christian Identity ministry was placed in the following categories: 1) affiliated beliefs include people who identify as Christian; 2) unaffiliated beliefs include people who identify as atheist, agnostic, or state they adhere to no religion; and 3) pseudo-religious beliefs include pagans, Cosmotheists, and Christian Identists. ${ }^{3}$ Refer to Table 1 for a breakdown of white nationalist religious perspectives.

Table 1. White Nationalist Religious Perspectives*

\begin{tabular}{|l|c|}
\hline Affiliated Religious Beliefs & 263 \\
\hline Protestant & 150 \\
\hline Catholic & 16 \\
\hline Mormon & 10 \\
\hline Pentecostal & 439 \\
\hline Total & $45 \%$ \\
\hline Percentage of $N$ & \\
\hline Unaffiliated Beliefs & 190 \\
\hline Atheist/Agnostic/None & $19 \%$ \\
\hline Percentage of $N$ & \\
\hline Pseudo-religious Beliefs & 159 \\
\hline Christian Identity & 194 \\
\hline Other** & 353 \\
\hline Total & $36 \%$ \\
\hline Percentage of $N$ & \\
\hline N-982 &
\end{tabular}

$\mathrm{N}=982 \quad 100 \%$

*Sources: 9 Stormfront Polls Dealing with White Nationalist Religious Beliefs (2003 through 2013). 35 Members of Pastor Thom Robb's Christian Identity Sect in Zinc, Arkansas (2010 through 2012). When asked how they currently identify, all 35 people affiliated with Pastor Robb's congregation selected Christian Identity. Some of the newer and younger members still adhered to a variety of neo-Nazi beliefs and expressed admiration for Hitler. Others said they are Christian but like the Identist approach to race. Pastor Robb and his wife are included in the final count of 35 .

**Other includes various alternative belief systems such as Cosmotheism, Creativity, Wotanism and Odinism.

A sampling of Stormfront discussion data from the Theology Discussion Forum includes the first two topics. The third topic was housed under the Ideology and Philosophy Discussion Forum. Unlike the first two topics, this discussion was not a sub-forum.

1. The Religion of Adolf Hitler ${ }^{4}$ : located in the Cosmotheism/Creativity sub-forum of Theology

2. Thinking of becoming $C I^{5}$ :located in the Christian Identity sub-forum of Theology

\footnotetext{
${ }^{3}$ Some Christian Identists also say they are Christian even though they do not adhere to the basic Christian tenet of love for your neighbor, no matter the race.

${ }^{4}$ http://bit.ly/2fZ3b7A

${ }^{5}$ http://bit.ly/2f7Lzc2
} 
3. Cosmotheist Ideology/Philosophy ${ }^{6}$ : located in the Ideology and Philosophy forum

Analysis of the Stormfront data began on August 4, 2016 and ended on August 10, 2016. Discussion 1 contained a total of 83 posts, discussion 2 contained 109 posts, and discussion 3 contained 161 posts for a total of 353 .

\section{The Christian Revival Center (Zinc, Arkansas)}

The third source of data comes from members of Pastor Robb's church. Recorded interviews were conducted by me with 10 individuals who regularly attended church services at the Christian Revival Center from September 2010 to December 2012. Not all members of Robb's sect agreed to be interviewed and recorded; however, a total of 35 people (including the recorded interviews) shared religious affiliation information which is included in this study. Robb's church, library, and home is located on 300 acres in the Ozark region of Arkansas. Beginning in December 2010, Robb conducted a fundraising campaign to build a dormitory for students who enroll in the Soldiers of the Cross Training Institute held every summer on his property. Over a two year period Robb raised roughly half of the money $(\$ 20,000)$ needed to build the structure.

For many years Robb adhered to traditional CI dogma and teachings, but in 2010 he opened his Klan group, church, and training institute to individuals with neo-Nazi leanings. An example of this new recruitment strategy includes his willingness to admit members of the now defunct White Revolution. Some members of White Revolution made the move with Billy Roper, founder of the group, when he joined Robb's Klan group and church in August 2010. While Robb is expanding his membership to include skinheads and neo-Nazis, Christian Identity religious ideology still anchors both his Klan group and his church congregation (personal communication, September 2, 2012). Acutely aware of certain ideological differences with some of his newest members, Robb feels that race is the ultimate trump card that will unite white people and result in a rebirth of the nation envisioned by the founding fathers.

\section{Limitations of the Study}

It should be noted that the data from Stormfront and field research in Arkansas is limited in its focus due to the nature of convenience sampling. Additionally, because of the small sample size from Arkansas and the inability to verify the identity of Stormfront discussants, these findings cannot be generalized or considered directly representative of the broader population of people who identify in some way with the white nationalist movement. However, as the findings demonstrate there are consistent overlaps in racial attitudes and beliefs throughout the sample.

\footnotetext{
${ }^{6} \mathrm{http}: / /$ bit.ly/2fzKdr5
} 


\section{Findings}

Findings from analysis of Stormfront discussions and field work in Arkansas are included below. ${ }^{7}$

\section{Stormfront}

In The Religion of Adolf Hitler, James Harting began the discussion with the following post on November 9, 2015 at 1:15 PM:

The phrase "the religion of Adolf Hitler" can mean one of two different things: It can refer to a belief in Adolf Hitler as a religious figure. This belief has been championed by such post-War National-Socialists as Savitri Devi, Matt Koehl, and Miguel Serrano. Savitri called it the "Hitler Faith," while Miguel Serrano termed it "Esoteric Hitlerism." But the "religion of Adolf Hitler" can also refer to the personal religious beliefs which Hitler held himself--which are quite different from Esoteric Hitlerism! Here is an article on the second of these options, that is, Hitler's own personal appreciation of the Divine. The Truth About Hitler| Verum Serum. The article includes a stupid section entitled "Rewriting the Bible," which has nothing to do with Hitler at all. Otherwise it is the most accurate and perceptive account of Hitler's religiousness which I have read.

On November 10, 2015 at 5:59 PM, a discussant, The Q posted:

Here's the truth: Hitler was raised a Catholic but eventually in adulthood decided that he was an atheist. That's it. Period.

In response Coldstar posts on the same evening at 9:16 PM:

I understand that Hitler was raised as a Roman Catholic but he did not remain an official member in adulthood. It is not likely that he ever became an atheist. Rather he was interested in reviving early Christianity which knew that Jews were the enemy of all things right, decent and good. Hitler cleaned up the Jewish filth of lewd entertainment as one of his first acts after he came to power.

The discussion continues with arguments over whether or not Hitler was a Christian or an atheist. Several people quote directly from Hitler's speeches and Mein Kampf to support their claims that he was, in fact, a Christian and a believer in God. The discussion goes on for several days and there are embedded YouTube videos and other links along with quotations from Hitler on the topic of religion. Some of those quotations include the following:

\footnotetext{
${ }^{7}$ None of the data has been edited. For that reason there are numerous grammatical and spelling errors throughout. Some discussants use their real names such as Billy Roper who has a long history with the white nationalist movement as a leader and activist.
} 
Hence today I believe that I am acting in accordance with the will of the Almighty Creator. By defending myself against the Jew, I am fighting for the work of the Lord.

The unprecedented rise of the Christian Social Party was to assume the deepest significance for me as a classical object of study.

The root of the whole evil lay in the fact that the directing body of the Catholic Church was not in Germany and that for this very reason alone it was hostile to the interests of our nationality.

The discussion ends somewhat benignly on May 7, 2016 at 4:11 PM with a post by a discussant called HansSachsSohn.

It was interesting to find that (National Socialist) Party members could designate their religious status as "Gottglaubig", believer in God, without further modification, and therefore not commit themselves to the sort of political conflicts involved with further confessional struggles (or at least, try not to). The profound sense of Destiny or Fate is very strong in the German character generally -- that may well be the element that so marks the ascent of German composers from the classical through late Romantic eras -- and the sense that this conflict is engraved in the ultimate realities with which we deal is essential to the religious mindset of the Volk.

The second discussion forum analyzed in this paper, Thinking of Becoming CI, began on October 29, 2010 at 1:14 AM. Discussant Define Normal begins the discussion with the following post:

Right now I practice Traditional Christianity, but there are parts of it that nag me. First of all is the rampant Jew and Israel worship. It's insane. Many pastors even have Israeli flags in their offices. The term "JudeoChristianity" grinds my gears. Second, I believe that Christ was correct in calling the Jews children of Satan.

John 8:44 - "You are of your father the devil, and the desires of your father you want to do. He was a murderer from the beginning, and does not stand in the truth, because there is no truth in him. When he speaks a lie, he speaks from his own resources, for he is a liar and the father of it."

John 8:48 - "Then the Jews answered and said to Him, "Do we not say rightly that You are a Samaritan and have a demon?"

It's obvious, for all to see, that Jesus was talking to the Jews. I'm bothered that many modern Bible translations remove the term "the Jews" and instead use "the people". 
Third, I believe that Whites are the people chosen by God, that Christ was White, as were the prophets. This is not a view shared by traditional Christianity. Are there any CI churches in Phoenix, Arizona? If so, I would like to attend one, at least once, and speak with a pastor.

Define Normal gets some encouragement from other Stormfront members.

Nayto responds at 5:43 AM:

If you can't find a group of CI people in your area then there are plenty of online CI study materials you can keep busy with. Just pray and ask faithfully for Father to give you some people to fellowship with in person. There are also a few very knowledgeable people in this very board who you could talk to and ask questions.

Welcome to the truth, cousin :)

Haus Drachen follows at 9:39 AM

Sounds like you already ARE CI, brother. :D

Later that same day at 11:37 PM, PatriotKKK posts a response:

Greetings Brother. First off I feel somewhat obligated to state that what you describe as "traditional Christianity" is not traditional Christianity, nor even Christianity at all. If it is not consistent with scripture, then it's false, as there is no denomination in GOD's truth. You honestly can't get any more traditional than CI.

Now considering your current understanding of scripture, it sounds to me like you are no doubt already an Identity Christian. It's always uplifting to see my Brethren not allowing the wool to be pulled over their eyes. Good luck on your search for a good Church in your area, as I know they are very hard to come by. If I discover any I will surly let you know.

\section{YHVH Bless!}

Billy Roper joined the discussion thread on January 14, 2014 at 6:40 AM:

When I regained my faith after miserably being agnostic most of my life, it was easier for me to accept single seedline, at first, because it seemed less...different from the Southern Baptist upbringing I had been raised with but rebelled against as a teenager because of the Jew worship hypocrisy in mainstream SBC. Less mythological or supernatural, if you will, less of a leap of faith. It took me some time to embrace DS. 
Had it not been for the opportunity to travel with and spend time talking to Pastor Butler, and his openness to me in discussing CI, and later Pastor Robb's, I probably wouldn't have ever made it back.

I understand the position some hold that we my believe DS but have better chance of recruiting people if we teach SS, therefore...but if we do that, to me that makes us like the mainstream preachers who know the truth about race but ignore or deny it entirely.

The third and final Stormfront discussion deals with Cosmotheism. The thread was started by Will Williams on January 31, 2015 at 8:28 AM.

This topic is for expression of Dr. William Pierce's Nietzschean world view. Articles by him will be posted here as well as links to the National Alliance's American Dissident Voices broadcasts which follow the Founder's Cosmotheist teachings. Some will argue that Cosmotheism should be limited to the tiny, moribund Cosmotheist/Creativity subsection of the Theology Section of Stormfront because Dr. Pierce's world view can also be seen as a religion for White people. We hope this important topic will not be shut down and removed altogether as another long-running one was that was here in Ideology and Philosophy.

Cosmotheism: Wave of the Future

Discussant Williams is a Cosmotheist who posts frequently on Stormfront. $\mathrm{He}$ is also a member of National Alliance and is trying to resuscitate the group following years of decline since the death of Dr. Pierce in 2000.

At 4:26 PM Sonderweg responds to Williams' post which included links to Dr. Pierce's writing:

Thanks for sharing and promoting Dr Pierce writings. I admire and respect Ben Klassen (founder of the Creativity Movement, another pseudoreligious perspective that is popular among some Stormfront members) and Dr Pierce... Sometimes its quite difficult to separate philosophy/ ideology from religion because traditional and mainstream religion implicitly contains a sort of philosophy (many times very sketchy and weak to compete to real philosophy as biophilosophy), the dogmatism of the religion belivers its a mayor obstacle to interchange of ideas, only a weak ideology needs special protections, taboos and prohibitions, only a nonsensical ideology could ask the people blind faith, thats the big difference between solid and good philosophies (as Creativity and Cosmotheism to name some) and obsolete, jewish rooted dogmatic creeds.

The next morning, February 1, 2015 at 7:07 AM, brings a question from Vitez Srpstvo: 
Could somebody explain what Cosmotheism is about? Wikipedia doesn't give any information about this. Is it something about the Cosmo being the super power / god?

This question elicits a somewhat irritated response later that same day (3:41 PM) from Will Williams:

Something like that.: rolleyes: Wikipedia won't tackle that question from a White racial perspective. Robert S. Griffin delved into Cosmotheism a bit with Dr. Pierce in his book The Fame of a Dead Man's Deeds

How did William Pierce's Cosmotheism, begin? How did it develop? Dr. Griffin asked Dr. Pierce these and other questions, and here are the answers.

He posts numerous excerpts from Robert Griffin's biography of William Pierce along with more writings from Pierce himself. This discussion thread goes on for many pages, most of which contain links to Pierce's writings, YouTube videos of his sermons and other talks. Some discussion posts also degenerate into name calling when a Catholic discussant is offended by Pierce's paganistic tendencies and anti-Semitism.

\section{Christian Revival Center}

After moving his entire family from Detroit, Michigan to the remote community of Zinc, Arkansas in 1980, Christian Identity minister and Klansman, Thom Robb, established his Christian Identity ministry and church, the Christian Revival Center. Robb's enclave community is unique in that it provides one stop shopping for contemporary Christian Identists that includes a church, library of extremist books and pamphlets, annual events such as rallies and educational conferences, and a training institute for white nationalists. The religious dogma espoused by Identity theologians such as Pastor Robb is a revisionist version of traditional Christianity that claims whites are the chosen people of God and created in His likeness. Pastor Robb's message is that religion and race are inseparable and that Christian Identity recognizes the superiority and exceptionalism of white people. Below is a portion of one of Robb's sermons (December 11, 2011):

Through a mass distortion of history, modern day Christians have been deceived and lied to about the importance of their blood heritage. Our people, white people, are the ones who conquered all the continents and mapped the stars. Now we are facing genocide and unenlightened whites continue to ignore the facts. This congregation has heard the call to find a way to save some of our people through racial redemption. 
Based on my findings, 35 adults consistently attended services at the Christian Revival Center and claimed membership in the sect. Some, not all, are members of The Knights Party, Robb's Klan group. Pseudonyms are used for all interviewees with the exception of Billy Roper, his ex-wife, Stacy, and comments from Pastor Robb.

When asked how she became a Christian Identist, Stacy Roper had the following to say:

I grew up in the skinhead culture out in California so I didn't become aware of Identity until I moved out here to Arkansas and married Billy. Then with my recovery from drugs I needed some stability and I found that with Pastor Robb's church family. I used to be a paganist but now I'm totally into CI. Stacy Roper, interview date August 11, 2010

Before Stacy and Billy got married, he was agnostic. She convinced him to attend church services and eventually he joined Pastor Robb's church and the Knights Party and declared as Christian Identist. He also shut down his Web site promoting White Revolution in August 2010. On the surface Roper's new religious perspective seemed to contradict much of his neo-Nazi ideology and agnosticism. When asked about that, he explained the connections that CI has to the broader white nationalist movement.

Within the white nationalist movement there is a resurgence of Christian Identity. The old Klan was strictly CI and they wouldn't associate with any other groups - especially skinheads. Now lots of guys come out of prison as Aryan Brotherhood and they want to have some continuity with their racist beliefs so they find a home in CI....so now you have a strain of Christian Identity among the younger folks who are not Klansmen that is on the ascendancy. Then you have the Creativity worldview from the Matt Hale - Ben Klassen wing of the movement and agnosticism and even Odinism - that's the connection to Nazism. It just made sense for me to make the leap from being agnostic to CI. And church means a lot to Stacy so I just sort of fell in line with that as many husbands do. Billy Roper, interview date August 11, 2010

Gary was a member of White Revolution for many years. When Roper joined ranks with Pastor Robb, he brought several people with him. When asked about his beliefs, Gary had this to say.

I am a Christian, although I am probably not what you would call a mainstream Christian. Sometimes I go to regular Baptist church services when I am over in central Arkansas but I prefer Pastor Robb's approach to the ministry. Even when I was in White Revolution, I went to church ingrained as a kid I suppose. 
I also identify as a white ethnic nationalist and I don't like Jews so there you have those Christian Identity leanings. I have always admired Hitler and what he tried to accomplish in Germany. When I was younger I used to like reading about the fight for the German Aryan soul. I can't say that I've ever been officially pagan but I tinkered with it in the past. Right now I'm doing the CI thing. Gary, interview date December 12, 2011

Ryan, another former member of White Revolution, was attending the Christian Revival Center in 2012. When asked about his views on Christian Identity he explained it this way:

The U.S. has become the Babylon of the West. There is so much sin and greed and corruption that we'll never recover so us enlightened whites just sort of gravitate to a religion like Christian Identity. Some of our younger members still have their pagan ways and they are trying to resolve that with CI beliefs. Mainstream religion just doesn't do it for most of the people in the movement so Pastor Robb's church serves a real important purpose for a lot of folks - especially ones with families. Ryan, interview date, December 10, 2012

\section{Discussion}

Findings from the Stormfront poll data and from field work with Pastor Robb's Identity sect are compared to mainstream beliefs represented in a survey by Lugo and Cooperman (2012) for the Pew Trust at http://bit.ly/2g9JSfu. Affiliated religious beliefs are defined by individuals who describe their faith in terms of Protestant or other Christian categories. Unaffiliated beliefs are defined by individuals who describe their religion as atheist or agnostic or none at all. The term pseudo-religion is used to categorize Christian Identity and other alternative belief systems such as Cosmotheism and Creativity that some members of Stormfront and the Christian Revival Center adhere to. Lugo and Cooperman (2012) found that $48 \%$ of their respondents describe themselves as Protestant compared to $27 \%$ of the respondents in this study. Approximately $15 \%$ of white nationalists represented in the Stormfront poll data identify as Catholic compared to $22 \%$ in the Pew report. Nineteen percent of white nationalist respondents stated they were unaffiliated as did $19 \%$ of the Pew sample. Lugo and Cooperman's 2012 survey included people from all racial/ethnic categories while the sample represented in this study is assumed to be racially homogenous. ${ }^{8}$

Regarding pseudo-religious beliefs, $36 \%$ of the sample is in this category. Christian Identists represent $16 \%$ and the other category that includes Cosmotheism and pagan beliefs represents $20 \%$ of those polled. One of the

\footnotetext{
${ }^{8}$ I can verify that all members of the Christian Revival Center are white; however, since Stormfront is an open forum that often attracts people who may not be affiliated with the movement or even members of the forum, there may be some participants in either the discussions or polls who are actually Jewish, anti-racist whites or people of color.
} 
questions asked of members of the Christian Revival Center was clarification regarding earlier group affiliation. ${ }^{9}$ Even though members of the sect overwhelmingly identify as Christian Identity, ten individuals admitted that their belief system still contains pagan elements emanating from their neo-Nazi leanings. These people were also younger than other members of the sect. The average age of members during the two years of field work represented in this paper was around 45.

What do these statistics reveal about a social movement that has often been defined by its connections to both Christian Identity and pagan belief systems and linked to uneducated Klansmen from the rural South? Roughly $45 \%$ of the sample classify themselves as having some affiliation with Christianity. Unaffiliated white nationalists are able to avoid the debate surrounding the divide between Christian tenets of love, tolerance and forgiveness and overtly racist beliefs. They are not believers; therefore, hatred of other races has nothing to do with any non-secular religious perspective. For Christian Identists they cling to reinterpretations of scripture laid out by Wesley Swift and preachers who came after him exemplified by Thom Robb. For Cosmotheists such as Will Williams of Stormfront, he hopes to introduce newcomers to Dr. Pierce's great white hope and vision for a new white centered universe.

According to Piper (2011: 76), the growth of movements that embrace racist religious ideologies often create an "evangelical blind spot" in support of a white centered, androcentric America. Even though Christian Identity and Cosmotheism are categorized in this paper as pseudo-religions, they still contain structural dimensions that enable racist attitudes among a segment of the white population who self-identify as white nationalist. Their beliefs undermine Christian teachings that anyone who believes the word of God (no matter their race) and trusts in Jesus Christ can be saved and forgiven of their sins (Olson and English 2005: 72). Analysis of Stormfront posts reveals that belief systems are highly influenced by those espoused by Hitler, Swift, and Pierce.

In the first discussion about Hitler's religion, discussants argue the finer points of Hitler's true religious beliefs; however, there was no indication that anyone who participated in the discussion hated Hitler or disapproved of what he did to the Jews during the holocaust. Additionally, one has to wonder if they have ever read a scholarly article or book dealing with Hitler's life before and during his rise to power in Germany. The analysis of this discussion does not indicate any reading beyond some of his speeches and quotations from Mein Kampf although some discussants claimed that Hitler was an atheist or a believer in some ancient Nordic pagan mythology. As Fabricius (1937) stated, Hitler held many hysterical beliefs about religion and ideological politics, always managing to justify his fight for the German people against Jews by invoking the word of God.

\footnotetext{
${ }^{9}$ Example: Prior to joining the Christian Revival Center, what group(s) were you a member of? Some answers included: White Revolution, Blood \& Honour, no other group, and National Alliance when Dr. Pierce was alive.
} 
In the second discussion dealing specifically with Christian Identity, comments were consistent with anti-Semitic and racist beliefs. Most discussants had at least some familiarity with Wesley Swift and two other Christian Identity ministers, Bernard Comparet and Sheldon Emry, were also mentioned. They also appeared to be using the Internet to gain access to CI books and pamphlets in order to learn more. Implicit in the discussion was a general discomfort among the discussants with traditional Christian beliefs of forgiveness and loving one's neighbor as oneself no matter the race. Discussants also appeared to be comfortable with the idea that whites are superior to other races.

Finally, William Pierce still appears to influence some members of Stormfront while others are being introduced for the first time to his thought and ideology. Will Williams, a Stormfront member since 2007, has a good general understanding of Cosmotheism and seems to be trying to educate people who want to learn more. He is also trying to recruit new members to National Alliance. He does this by posting links to the group and talking about what they are trying to accomplish within the broader white nationalist movement. His user profile reveals that his total posts on the site number 887 and he is a member of eight social groups, most of which are neo-Nazi. His user profile contains the following quote from Pierce:

We need ethics; we need values and standards; we need a world view. And if one wants to call all of these things together a religion, then we need a religion. One might choose instead, however, to call them a philosophy of life. Whatever we call it, it must come from our own race soul: it must be an expression of the innate Aryan nature. And it must be conducive to our mission of racial progress. -Dr. William Pierce, in National Alliance Membership Handbook

Several interviews with people who attend church at the Christian Revival Center reveal that even though they may not fully embrace Christian Identity, they do support Pastor Robb's efforts to bring white people together for the purpose of racial enlightenment. They universally idealize whites as God's chosen people and demonize Jews as immoral and greedy. There were also several comments about the importance of fighting for the white race and keeping the bloodline pure. During the time that I attended church services and listened to Pastor Robb's sermons, his message of white superiority, racial endogamy, and total separation of the races was consistent. I also found that the people I met do not view themselves as irrational fanatics, but rather as keepers of their own brand of faith.

\section{Conclusion}

The need to expose and explain theological underpinnings that ground the broader white supremacist movement are critical to understanding racialist interpretations of the Bible. Black (2001) and Godman (2004) suggest that 
racist movements may become entangled with mainstream businesses, political parties, and religious institutions. Racist ideology and rhetoric threatens both liberal and conservative American values. In some instances well-meaning people become unwitting dupes for pseudo-scientific and pseudo-religious ideas espoused by charismatic extremists such as the late Wesley Swift and William Pierce.

While people with extreme racist religious beliefs appear to be a relatively small percentage of the general population, this study illustrates similarities between their religious perspectives and the mainstream Pew sample. As the white nationalist movement continues to evolve and change along with people who align themselves with the various groups that constitute the movement, it is imperative for social researchers to investigate subtle shifts that are occurring in educational attainment, religious affiliation, and political initiatives in the population. According to Collins (2004: 51), when ideologies that defend racism and heterosexism become taken-for-granted and appear to be natural and inevitable, they become hegemonic. Few people question them and the social hierarchies they defend.

White supremacy in the United States is constantly evolving and sites like Stormfront provide a contemporary overview of the movement along with profiles of people who align with the movement and join the virtual community. When average whites (who do not think that much about racism) fail to understand how white supremacist beliefs can seep into mainstream rhetoric, they miss the structure of embedded racist domination that permeates Internet sites like Stormfront. Future research should include more investigation about how social media and other technologies are impacting the white nationalist movement in the United States and abroad. Field work can be challenging; however, one of the best ways to learn what drives individuals to join extremist groups, embrace pseudo-religions such as Christian Identity, and post in forums on sites such as Stormfront is to question them about their beliefs and lives, observe events, and document those findings.

\section{References}

Barkun M (1994) Religion and the racist right: The origins of the Christian Identity Movement. Chapel Hill, NC: University of North Carolina Press.

Barkun M (2006). Purifying the "of "Christian Patriots". Journal for the Study of Radicalism 1(1): 57-70.

Black E (2001) IBM and the holocaust: the strategic alliance between nazi Germany and America's most powerful corporation. NY: Crown Publishers.

Bowman-Grieve L (2009) Exploring "Stormfront": A virtual community of the radical right. Studies of Conflict \& Terrorism 32: 989-1007.

Brown C (2009) White supremacist discourse on the internet and the construction of whiteness ideology. The Howard Journal of Communications 20: 189-208.

De Koster W, Houtman D (2008) "Stormfront is like a second home to me" on virtual community formation by right-wing extremists. Information, Communication \& Society 11(8): 1155-1176. 
Dobratz B (2001) The role of religion in the collective identity of the white racialist movement. Journal for the Scientific Study of Religion 40(2): 287-302.

Dobratz B, Waldner L (2016) The White Power Movement's Populist connection to the Tea Party Movement in the United States. Athens Journal of Social Sciences 3(3): 181-194.

Douthat R (2013) Bad religion: How we became a nation of heretics. NY: Free Press.

Durkheim E (1912/1955) The elementary forms of religious life. NY: Free Press.

Eysenbach G, Till JE (2001) Ethical issues in qualitative research on internet Communities. British Medical Journal 323(7321): 1103-1105.

Fabricius C (1937) Positive Christianity in the third Reich. Dresden, Germany: Hermann Pũschel.

Godman P (2004) Hitler and the Vatican: Inside the secret archives that reveal the new story of the Nazis and the Church. NY: Free Press.

Goldberg M (2007) The rise of Christian nationalism: Kingdom coming. London: Norton.

Goodwin MJ (2011) New British fascism: The rise of the British National Party. London: Routledge.

Hebdige D (1979/2001). Subculture: The meaning of style. London: Routledge.

Hijmans E (1996) The logic of qualitative media content analysis: a typology. Communications 21: 93-108.

Hill Collins P (2004) Black sexual politics: African Americans, Gender and the New Racism. NY: Routledge.

Kaplan J (1993) The context of American millenarian revolutionary theology. Terrorism and Political Violence, 5: 30-82.

Krippendorff K (2004) Content analysis: An introduction to its methodology. London: Sage.

Lugo L, Cooperman A (2012) "Nones' on the rise. Retrieved from http://pewrsr.ch/ Kw35Vq. [Accessed August 9, 2016].

Meddaugh P M, Kay J (2009) Hate speech or "reasonable racism?" The other in Stormfront. Journal of Mass Media Ethics 24: 251-268.

Milwicki A (2014/2015) Baptizing nazism: An analysis of the religious roots of American neo-Nazism. Journal of Hate Studies 12(1): 73-100.

Olson RE, English AC (2005) History of theology. Downers Grove, IL: Intervarsity Press.

Ostendorf D (2001/2002) Christian identity: An American heresy. Journal of Hate Studies, Vol. 4(1): 23-54.

Paccagnella L (1997) Getting the seats of your pants dirty: strategies for ethnographic research on virtual communities. Journal of Computer-Mediated Communication 3(1). Retrieved from http://bit.ly/2fSZVLD. [Accessed 1 August 2016].

Pierce W (1977) The path. Retrieved from http://bit.ly/2g9OL8f. [Accessed 1 August 2016].

Pierce W (1979) Cosmotheism: On living things. Retrieved from http://bit.ly/2g9OL8f. [Accessed 1 August 2016].

Pierce W (1984) Cosmotheism: on society. Retrieved from http://bit.ly/2g9OL8f. [Accessed 1 August 2016].

Piper J (2011) Bloodlines: race, cross, and the Christian. Wheaton, Illinois: Crossway.

Ridgeway J (1990) Blood in the face. New York: Thunder's Mouth Press.

Sharpe T T (2000) The identity Christian movement: Ideology of domestic terrorism. Journal of Black Studies 30(4): 604-623.

Simi P, Futrell R (2010). American swastika: Inside the White PowerMovement's hidden spaces of hate. Lanham, MD: Rowman \& Littlefield.

Vierick P (1941/1961) Meta-politics: The roots of the Nazi mind. New York: Capricorn. 
Weatherby G A, Scoggins B (2005/2006) A content analysis of persuasion techniques used on white supremacist websites. The Journal of Hate Studies 4: 9-31.

Zeskind L (2009) Blood and politics: the history of the White Nationalist Movement from the margins to the mainstream. New York: Farrar Strauss Giroux.

\section{Addendum}

Stormfront Polls in date order*

What are you? http://bit.ly/2fJwSwH. [29 June 2003].

What religion were you born into? http://bit.ly/2fwcrAb. [29 July 2004].

What beliefs do you follow? http://bit.ly/2fT2U72. [17 April 2005].

What are your beliefs? http://bit.ly/2gAaO9M. [22 December 2005].

What religion do you ascribe to? http://bit.ly/2ff527m. [26 January 2006].

What is your religion? http://bit.ly/2eVZxz3. [4 February 2007].

Which of these choices describes you the best http://bit.ly/2eVUw9O. [13 December 2007].

What religion are you? http://bit.ly/2ff6kiL. [4 Mars 2012].

Which Christian Denomination is the most Biblically correct? http://bit.ly/2fJud5N. [9 December 2012].

*Only polls with at least 50 responses were included in this study. Incoherent comments were not included in the poll data nor were responses that did not reflect a quantifiable religious perspective as categorized in the typology adapted from the Pew Report. 